\title{
Mononucleated Blood Cell
}

National Cancer Institute

\section{Source}

National Cancer Institute. Mononucleated Blood Cell. NCI Thesaurus. Code C73123.

A mixture of cells possessing a single nucleus, including monocytes and lymphocytes;

blood leukocytes from which granulocytes have been separated and removed. 